\title{
Activismo artístico y memoria: el caso de la desaparición de Santiago Maldonado*
}

ARTISTIC ACTIVISM AND MEMORY: THE CASE OF SANTIAGO MALDONADO'S DISAPPEARANCE

ATIVISMO ARTÍSTICO E MEMÓRIA: O CASO DA DESAPARIÇÃO DE SANTIAGO MALDONADO

\section{Verónica Cecilia Capasso** Ana Liza Bugnone***}

Cuadernos de Música, Artes Visuales y Artes Escénicas

/ Volumen 14 - Número 2 / Julio - Diciembre de 2019

/ ISSN 1794-6670 / Bogotá, D.C., Colombia / pp. 23-41

Fecha de recepción: 29 de septiembre de 2018

Fecha de aceptación: 19 de febrero de 2019

Disponible en línea: 25 de julio de 2019

doi 10.11144/javeriana.mavae14-2.aaym

* Artículo de investigación derivado de la labor realizada en la línea de investigación Arte, estética y política, perteneciente al Área de Estudios Políticos Latinoamericanos de la Facultad de Humanidades y Ciencias de la Educación, Instituto de Investigaciones en Humanidades y Ciencias Sociales, Universidad Nacional de La Plata-Consejo Nacional de Investigaciones Científicas y Técnicas (Conicet).

* Licenciada en Sociología y en Historia del arte por la Universidad Nacional de La Plata, magíster y doctora en Ciencias Sociales por la misma universidad. Diplomada en Cultura Brasileña por la Universidad de San Andrés. Becaria Posdoctoral de Conicet en el Instituto de Investigaciones en Humanidades y Ciencias Sociales, Universidad Nacional de La Plata. Profesora ayudante diplomada de la Facultad de Humanidades y Ciencias de la Educación de la misma universidad.

ORCID 0000-0003-3202-4106

*** Licenciada en Sociología por la Universidad Nacional de La Plata y doctora en Ciencias Sociales por la misma universidad. Diplomada en Cultura Brasileña por la Universidad de San Andrés. Profesora adjunta de la Facultad de Humanidades y Ciencias de la Educación de Universidad Nacional de La Plata. Investigadora en el Instituto de Investigaciones en Humanidades y Ciencias Sociales.

ORCID 0000-0002-6674-717X

\section{Cómo citar:}

Capasso, Verónica Cecilia y Ana Liza Burgnone. 2019. Activismo artístico y memoria: el caso de la desaparición de Santiago Maldonado. Cuadernos de Música, Artes Visuales y Artes Escénicas 14 (2): 23-41. http://doi.org/10.11144/javeriana.mavae14-2.aaym 
Resumen

En este artículo, proponemos analizar un corpus de intervenciones estéticas que a través de diversos soportes y materialidades tuvieron lugar en espacios públicos y en las que se pedían por la aparición con vida de Santiago Maldonado. El 1 de agosto de 2017 desapareció Maldonado en Cushamen, provincia de Chubut, Argentina, en el contexto de desalojo de la comunidad mapuche y de una violenta represión por parte de Gendarmería Nacional Argentina. El caso tuvo rápida repercusión local e internacional. Se reclamó su aparición con vida y se sucedieron manifestaciones en todo el país, en las que el recurso artístico adquirió centralidad. A partir del análisis del corpus, arribamos a la conclusión de que las imágenes creadas construyeron enemigos, responsables de la desaparición forzada (principalmente el Estado, a través de la referencia al presidente Mauricio Macri y a la ministra de Seguridad de la Nación, Patricia Bullrich). Además, la utilización del rostro de Maldonado, derivado de una fotografía, retomó la construcción de la imagen de los desaparecidos argentinos durante la última dictadura cívico-militar, que se constituyó, no solo en el soporte material de la memoria, sino también en una conexión entre los desaparecidos en dictadura y en democracia. Por último, los recursos estéticos, emprendidos por diferentes grupos de la sociedad civil, funcionaron como un repertorio de acciones sustanciales para la política desde el punto de vista de la oposición al orden dominante, la visibilización de demandas y las prácticas de solidaridad. Metodológicamente, partimos de una perspectiva interdisciplinaria que nos permite describir y analizar las intervenciones estéticas surgidas en el contexto de diferentes acciones sociales y políticas.

Palabras clave: intervenciones estéticas; Argentina; desaparición forzada; espacio público; Santiago Maldonado.

\section{Abstract}

The this paper, we propose the analysis of a corpus of aesthetic interventions that took place in public spaces through different supports and materialities and asking for Santiago Maldonado to be returned alive. Maldonado disappeared on August 1, 2017, in Cushamen, Chubut province, Argentina, during the eviction of the Mapuche community and a violent repression by the Argentine National Gendarmerie. News of the case spread quickly at a local and international level. People asked for his safe return and followed with demonstrations throughout the country, with art taking on a central role. Based on the analysis of the corpus, we came to the conclusion that the images created enemies responsible for a forced disappearance (mainly the Government, through reference to President Mauricio Macri and the Minister for National Security, Patricia Bullrich). Furthermore, the use of Maldonado's face, taken from a photograph, resumed the construction of the image of those who disappeared in Argentina during the last civic-military dictatorship, which became not only the material support of memory, but also a connection between those who disappeared in dictator ship and in democracy. Finally, the aesthetic resources used by different social groups functioned as a repertoire of substantial actions for politics from the point of view of the opposition to the dominant order, the visibility of demands and practices of solidarity. In terms of methodology, we start from an interdisciplinary perspective that allows us to describe and analyze the aesthetic interventions emerging in the context of different social and political actions.

Keywords: aesthetic interventions; Argentina;

forced disappearance; public space; Santiago Maldonado.

\section{Resumo}

Neste artigo, propomos analisar um corpus de intervenções estéticas que ocorreram em espaços públicos através de várias mídias e materialidades e que pediam pela aparição com vida de Santiago Maldonado. No dia $1^{\circ}$ de agosto de 2017, Maldonado desapareceu em Cushamen, província de Chubut, Argentina, no contexto do despejo da comunidade Mapuche e da violenta repressão da Gendarmaria Nacional Argentina. O caso teve rápida repercussão local e internacional. Pediu-se pela sua aparição com vida e houve manifestações em todo o país, nas quais o recurso artístico um papel central. A partir da análise do corpus, chegamos à conclusão de que as imagens criadas construíram inimigos, responsáveis pela desaparição forçada (principalmente o Estado, através da referência ao Presidente Mauricio Macri e à Ministra da Segurança Nacional, Patricia Bullrich). Além disso, o uso do rosto de Maldonado, derivado de uma fotografia, retomou a construção da imagem dos desaparecidos da Argentina durante a última ditadura cívico-militar, que se constituiu não apenas no suporte material da memória, mas também em uma conexão entre os desaparecidos na ditadura e na democracia. Finalmente, os recursos estéticos, assumidos por diferentes grupos da sociedade civil, funcionaram como um repertório de ações substanciais para a política, desde o ponto de vista da oposição à ordem dominante, a visibilidade das demandas e as práticas de solidariedade. Metodologicamente, partimos de uma perspectiva interdisciplinar que nos permite descrever e analisar as intervenções estéticas que surgem no contexto de diferentes ações sociais e políticas.

Palavras-chave: intervenções estéticas; Argentina; desaparição forçada; espaço público; Santiago Maldonado. 


\section{INTRODUCCIÓN}

El 1 de agosto de 2017 desapareció Santiago Maldonado en Cushamen, provincia de Chubut, Argentina, en el contexto de desalojo de la comunidad mapuche y de una violenta represión por parte de Gendarmería Nacional Argentina, fuerza que opera en el ámbito del Ministerio de Seguridad del Poder Ejecutivo. El caso tuvo rápida repercusión local e internacional. Se pronunciaron diversos organismos de derechos humanos que reclamaban su aparición con vida y se sucedieron múltiples actos y manifestaciones en distintas ciudades del país en las que el recurso artístico adquirió centralidad. En este trabajo, nos proponemos analizar un corpus de murales que se emplazaron en espacios públicos de la ciudad de La Plata en los que se pedía por la aparición con vida de Maldonado. Estas intervenciones formaron parte de un conjunto de actos políticos que ubicaban la responsabilidad del Estado en la desaparición. Por un lado, parte de las imágenes creadas en torno a la desaparición de Maldonado construyeron enemigos, responsables de la desaparición forzada: el Estado (haciendo referencia al presidente Mauricio Macri y a la ministra de Seguridad de la Nación, Patricia Bullrich) y el poder económico (específicamente el empresario Luciano Benetton, propietario de terrenos que la comunidad mapuche reclamaba como propios). Por otra parte, la utilización del rostro de Maldonado, derivado de una fotografía, retomó la construcción de la imagen de los desaparecidos argentinos durante la última dictadura cívico-militar (19761983), que se constituyó no solo en el soporte material de la memoria, sino también en una conexión entre los desaparecidos en dictadura y en democracia. Por último, su rostro adquirió un lugar central en el contexto de la cultura visual actual, replicado masivamente por diversos espacios y medios de comunicación. Asimismo, los recursos estéticos, emprendidos por diferentes grupos de la sociedad civil, funcionaron como un repertorio de acciones sustanciales para la política, que visibilizaron lo sucedido, reclamaron justicia y se opusieron a los discursos sostenidos por el orden dominante.

El objetivo de este trabajo es describir y analizar algunos murales surgidos en las luchas por la aparición con vida de Santiago Maldonado y en el contexto de diferentes acciones sociales y políticas. Haremos foco en un corpus de murales de la ciudad de La Plata, realizados en 2017, año de la desaparición.

Metodológicamente, nos situamos desde una perspectiva interdisciplinaria como producción de conocimiento integral, lo que permite la articulación de distintas áreas del conocimiento, como los estudios sociales del arte, los estudios de lo urbano y la teoría política. De esta forma, promovemos un abordaje en el que las prácticas artísticas son interpeladas desde las fronteras de otras disciplinas.

En primer lugar, describiremos el contexto de la desaparición de Maldonado, seguidamente, haremos un repaso teórico por el concepto de activismo artístico y arte en el espacio público. Luego, a partir de la variedad de dispositivos artísticos que emergieron en relación con el caso, analizaremos un corpus de murales seleccionados y focalizaremos en el tipo de relación entre arte y política que observamos en estos casos. 


\section{CONTEXTO}

El pueblo mapuche históricamente ha enfrentado los intentos de conquista de las tierras que habitaba y, en particular, en la provincia del Chubut, Argentina. Gran parte de los reclamos mapuches actuales se orientan contra las propiedades rurales del Grupo Benetton que durante años ha ido adquiriendo cantidades ingentes de hectáreas en la Patagonia argentina. El 1 de agosto de 2017, durante el desalojo de la comunidad mapuche de Cushamen, provincia de Chubut, a través de una violenta represión por parte de la Gendarmería Nacional Argentina —-fuerza que opera en el ámbito del Ministerio de Seguridad del Poder Ejecutivodesapareció Santiago Andrés Maldonado. Santiago, de 28 años, era oriundo de la localidad 25 de Mayo, artesano y tatuador. A los 18 años, se mudó a La Plata (capital de la provincia de Buenos Aires) para estudiar Plástica en la Facultad de Bellas Artes, de ahí que el hecho haya tenido especial resonancia en esa ciudad. Unos meses antes de su desaparición se había instalado en El Bolsón (provincia de Río Negro), a unos $70 \mathrm{~km}$ de donde se denunció su desaparición. Maldonado apoyó a las comunidades indígenas en su reclamo por la propiedad de las tierras. Según amigos y familiares, fue capturado por la Gendarmería de manera forzada el día de la represión. ' Las acciones del Gobierno fueron tendientes a encubrir a los responsables y, junto con los medios de comunicación hegemónicos, culparon a la víctima, demonizaron a los pueblos originarios y los calificaron de terroristas.

Ante el hecho de su desaparición, diversos organismos de derechos humanos, instituciones y colectivos sociales y políticos se pronunciaron reclamando la aparición con vida de Santiago, así como se sucedieron múltiples actos y manifestaciones en distintas ciudades del país, en las que el recurso estético-artístico adquirió centralidad. Estas intervenciones, en general compuestas de recursos simples y fáciles de ser multiplicados, formaron parte de un conjunto de actos políticos que ubicaban la responsabilidad del Estado en la desaparición.

Por un lado, parte de las imágenes creadas construyeron enemigos, responsables de la desaparición forzada: el Estado (haciendo referencia al presidente Mauricio Macri y a la ministra de Seguridad de la Nación, Patricia Bullrich) y el poder económico (específicamente el empresario Luciano Benetton). Por otra parte, la utilización del rostro de Maldonado, derivado de una fotografía, se multiplicó en las calles y en las redes sociales a través de distintos dispositivos artísticos (stencils, murales, dibujos).

Maldonado estuvo desaparecido 78 días. El 17 de octubre del mismo año apareció su cuerpo sin vida en el río Chubut, $400 \mathrm{~m}$ río arriba de donde fue visto por última vez, aparentemente ahogado en el contexto de la represión de la Gendarmería, cuestión que aún está siendo investigada por la justicia.

\section{ALGUNAS BASES TEÓRICAS}

La producción de imágenes sobre la desaparición de Santiago Maldonado puede ser analizada en las prácticas del activismo artístico. Las prácticas estético-artísticas contemporáneas que se circunscriben a lo que se ha llamado activismo artístico pueden definirse a partir de múltiples características, teniendo en cuenta que se trata de un nombre originalmente autoadjudicado por el dadaísmo alemán. Según Longoni, se trata de "producciones

y acciones, muchas veces colectivas, que abrevan en recursos artísticos con la voluntad de 
tomar posición e incidir de alguna forma en el territorio de lo político" $(2011,43)$. Además, es sustancial mencionar que el arte activista, "en lugar de estar orientado hacia el objeto o el producto, cobra significado a través de su proceso de realización y recepción" (Felshin 2001, 74). El activismo artístico comúnmente tiene lugar en emplazamientos públicos, propicia el trabajo en red y de tipo colectivo (con otros grupos, asociaciones, movimientos sociales) y se caracteriza por el predominio de las acciones performáticas, a veces conectadas con los medios de comunicación (como espacio de producción o difusión). El aspecto colaborativo del activismo artístico permite la relación directa con la comunidad y facilita el acceso público a estas prácticas. Asimismo, esta característica favorece el impacto social y la continuidad del proyecto en cuanto está directamente vinculado con la comunidad o con ciertos grupos. Esto estimula la expresión de los colectivos sociales a través de estas prácticas, que se tornan sujetos con voz, visibles y activos.

Felshin (2001) agrega que el activismo artístico se inspira en formas de acción que provienen del mundo por fuera del arte. Sin embargo, podemos sostener que las prácticas que incorporan elementos extraartísticos no son nuevas, sino que vienen de las vanguardias históricas e hicieron énfasis en las década de 1960 y 1970 con el arte participativo (Bugnone 2018), por lo que la idea de que se toman del mundo por fuera del arte deja de tener sentido en cuanto ya fueron asumidos hace tiempo.

En este tipo de prácticas, es irrelevante la pregunta por el ser artístico, ya que el arte aparece como reservorio, como caja de herramientas, de técnicas y de estrategias. Otras dos características se destacan en estas propuestas: su "materialidad débil" (la apelación a recursos precarios, simples, sencillos y fáciles de ser multiplicados) y el "poner el cuerpo" en la práctica (Expósito, Vindel y Vidal 2012, 50). También surge en muchas ocasiones el planteo del disenso explícito o implícito en relación con el poder fáctico. Según Felshin (2001), esto ocurre porque cuestionan las representaciones culturales dominantes y ponen en evidencia las configuraciones del poder. En este sentido, la autora afirma que, más que realizar preguntas, en estos casos se intenta cambiar las reglas del juego junto con individuos y comunidades para estimular el cambio social.

Por otro lado, para el abordaje de las prácticas artísticas realizadas en el espacio público por la desaparición de Santiago Maldonado, también son necesarias herramientas provenientes de los estudios de lo urbano. Aquí existe una doble perspectiva: los procesos que producen la ciudad (producir la ciudad) y las formas sociales que se producen en la ciudad (producir en la ciudad), las que no se circunscriben solo a las actividades económicas, sino que incluyen aspectos sociales, políticos y culturales (Pírez 1995). Partimos, entonces, de la idea de que cada sociedad, en el entramado de sus relaciones, produce cierto espacio (Lefebvre 2013), lo que supone posicionarse, especialmente, desde dos afirmaciones. En primer lugar, considerar que el espacio es un producto social, histórico y político que "permite que tengan lugar determinadas acciones, sugiere unas y prohíbe otras" (Lefebvre 2013, 129). En segundo lugar, y en vinculación con lo anterior, el espacio no es reflejo, escenario ni telón de fondo sobre el que se inscriben los hechos sociales, sino que es producto y productor de relaciones sociales. Así, el espacio es soporte y campo de acción (Lefebvre 2013). Las prácticas sociales en general y las artísticas en particular no se insertan allí de forma "natural." Construyen espacio y pueden generar disrupciones en tanto se realizan en lugares no esperados, con modos que apelan a movilizar sentimientos y sentidos, y a despertar interés, curiosidad, cuestionamientos (Capasso 2016). 
Específicamente, entendemos por espacio público aquel territorio al cual todos tenemos acceso, podemos estar y circular, ya sean espacios abiertos, como plazas, calles, parques, ya sean espacios cerrados, como bibliotecas públicas, centros comunitarios, entre otros. El espacio público posee distintas dimensiones que lo definen: la físico-territorial, la política, la social, la económica y la cultural. Además, el espacio público puede ser definido como una esfera de relaciones - fundamentalmente conflictivas- que expresan una multiplicidad contemporánea, formada por una multitud de prácticas de contestación y negociación cotidiana (Massey 2008). A este respecto, lo público puede ser pensado como aquello que atañe a los asuntos colectivos (que concierne a la comunidad), como aquello que es visible y, por último, como aquello que es accesible y abierto para todos (Rabotnikof 2005). Consideramos que el espacio público se constituye de una manera dialéctica con las prácticas que en él tienen lugar, y en nuestro caso particular, en la relación con las intervenciones artísticas. Así, el espacio público es atravesado por una experiencia social al mismo tiempo que organiza esa experiencia y le da forma (Gorelik 1998).

Por último, podemos distinguir entre arte público y arte en el espacio público. El arte público generalmente está patrocinado, curado, avalado, evaluado e instalado por los representantes estatales que administran dichos espacios. Por otro lado, el arte en el espacio público se refiere a las acciones o propuestas que son gestionadas desde la sociedad civil y que, en muchas ocasiones, suponen un compromiso con el momento histórico y político que se vive. A continuación, daremos cuenta de la multiplicidad de prácticas artísticas realizadas en el espacio público a causa de la desaparición seguida de muerte de Maldonado para luego focalizar en un corpus de murales realizados en 2017 en distintos puntos de la ciudad de La Plata.

\section{ACTIVISMO ARTÍSTICO Y MEMORIA SOBRE SANTIAGO MALDONADO}

En el breve lapso de tiempo que va desde la desaparición de Maldonado y el presente, algunos trabajos académicos recogieron ciertos aspectos del tema. Así, la investigación de Gresham (2017) analiza el uso del retrato de Maldonado en relación con las fotografía de desaparecidos y la construcción de la memoria, en términos coincidentes con los de este artículo. Sin embargo, no trabaja específicamente sobre murales como aquí nos proponemos. Por otro lado, Soria (2017) reflexiona sobre las condiciones sociales y culturales de la desaparición de Maldonado y Vargas (2017) analiza brevemente la coyuntura de su desaparición desde un marco psicoanalítico, aunque no estudian las producciones visuales en torno a su desaparición.

La mayoría de los murales y de las imágenes que circularon por diferentes medios, como las redes sociales de internet y las pancartas, se basaron en una fotografía del rostro de Maldonado. Este uso hoy extendido de utilización de una imagen del rostro de una persona buscada —aplicable también a los resonantes casos de niñas y mujeres secuestradas por la trata de personas - nos remite inmediatamente a la construcción social y política de los retratos de personas desaparecidas que las Madres de Plaza de Mayo realizaron durante la última dictadura. Se trataba de fotografía de sus hijos e hijas, tomadas de carnés o de situaciones familiares o sociales, que las madres portaban en el espacio público, con el fin de identificar el rostro de la persona buscada. Al mismo tiempo, esa utilidad práctica adquiría una función 
simbólica ligada al reclamo por su aparición con vida y a la visibilización pública de lo que estaba aconteciendo durante la dictadura, situación negada e invisibilizada por gran parte de la sociedad argentina. Así, cada vez que las madres y otros familiares de desaparecidos salían a la calle, además del pañuelo que originalmente las había ayudado a reconocerse entre sí, llevaban esas imágenes que resguardaban el recuerdo vívido de un rostro joven, al mismo tiempo que hacían ver al resto de la sociedad que esas personas eran reales, tenían cuerpos y caras identificables, únicos. En relación con esto, debe decirse que no hay memoria sin imágenes, las cuales aparecen como necesarias dada la posibilidad de ver para entender, saber y conocer. Asimismo, estas imágenes funcionaron como referentes del reclamo hacia el Estado por el reconocimiento de los crímenes perpetrados por sus agentes, en momentos en que la Junta Militar, o bien negaba la existencia de los desaparecidos, o bien la reconocía en la frase de uno de sus exponentes más visibles, Jorge Rafael Videla, durante una conferencia en 1979: "Frente al desaparecido en tanto este como tal, es una incógnita el desaparecido [...] mientras sea desaparecido no puede tener un tratamiento especial: es un desaparecido, no tiene entidad, no está ni muerto ni vivo, está desaparecido" (Ámbito.com 2013, párr. 5). Todos estos sentidos que fueron cobrando las fotografías de los desaparecidos confluyen en una construcción política de estas imágenes. Esas prácticas que daban visibilidad a los desaparecidos formaron parte de la producción de la memoria del pasado reciente y quedaron en el recuerdo como paradigmas de la búsqueda de personas, especialmente en los casos de violaciones a los derechos humanos. Cabe mencionar que los carteles con las fotografías de los desaparecidos siguen vigentes en cada manifestación pública que se realiza en vinculación con el tema, en cada 24 de marzo cuando se recuerda el fatídico golpe de Estado que dio inicio a la dictadura, en los juicios en los que se investigan los crímenes cometidos durante el periodo, en los antiguos centros clandestinos de detención, en sitios de memoria, entre otros.

La fotografía del rostro de Santiago Maldonado (figura 1) se enlaza con esta memoria de la desaparición y, en particular, con su búsqueda, inicialmente con el mismo objetivo práctico que tuvieron las Madres de Plaza de Mayo de hacer visible su cara. Con el correr de los días posteriores a la desaparición de Maldonado, tomó cada vez más fuerza el valor de esa imagen como reclamo hacia el Estado, en el mismo sentido que el que había surgido tras la visibilización de los desaparecidos por las Madres de Plaza de Mayo. Otra vez el Estado aparecía como responsable de la desaparición, las violaciones a los derechos humanos estaban nuevamente a la orden del día y el rostro de Maldonado hacía confluir estos sentidos políticos de oposición al statu quo generado por una de las fuerzas del Estado.

Esta fotografía de Santiago Maldonado fue la base de la mayoría de las expresiones públicas visuales que reclamaban por su aparición con vida. Se tomó para la realización de stencils, pancartas, volantes en soporte papel y digital, murales e, incluso, máscaras que formaban caretas para ser usadas en las protestas. Asimismo, la difusión a través de las redes sociales de esta fotografía permitió su intervención y transformación en múltiples formas. Estas incluían su uso como fotografía de perfil en servicios de mensajería como WhatsApp y Facebook, y la utilización permanente e insistente de diversas formas de protesta visual digital frente a su desaparición. Al respecto, podemos señalar que la generación de estas diversas materialidades busca producir marcas -algunas permanentes, otras efímeras - en el espacio público para el recuerdo y el reconocimiento simbólico de lo que pasó y de sus víctimas. Estas marcas, como vehículos de memoria, son soportes "para el trabajo subjetivo y la acción colectiva, política y simbólica, de actores específicos en escenarios y coyunturas dadas" (Jelin 2017, 164). 


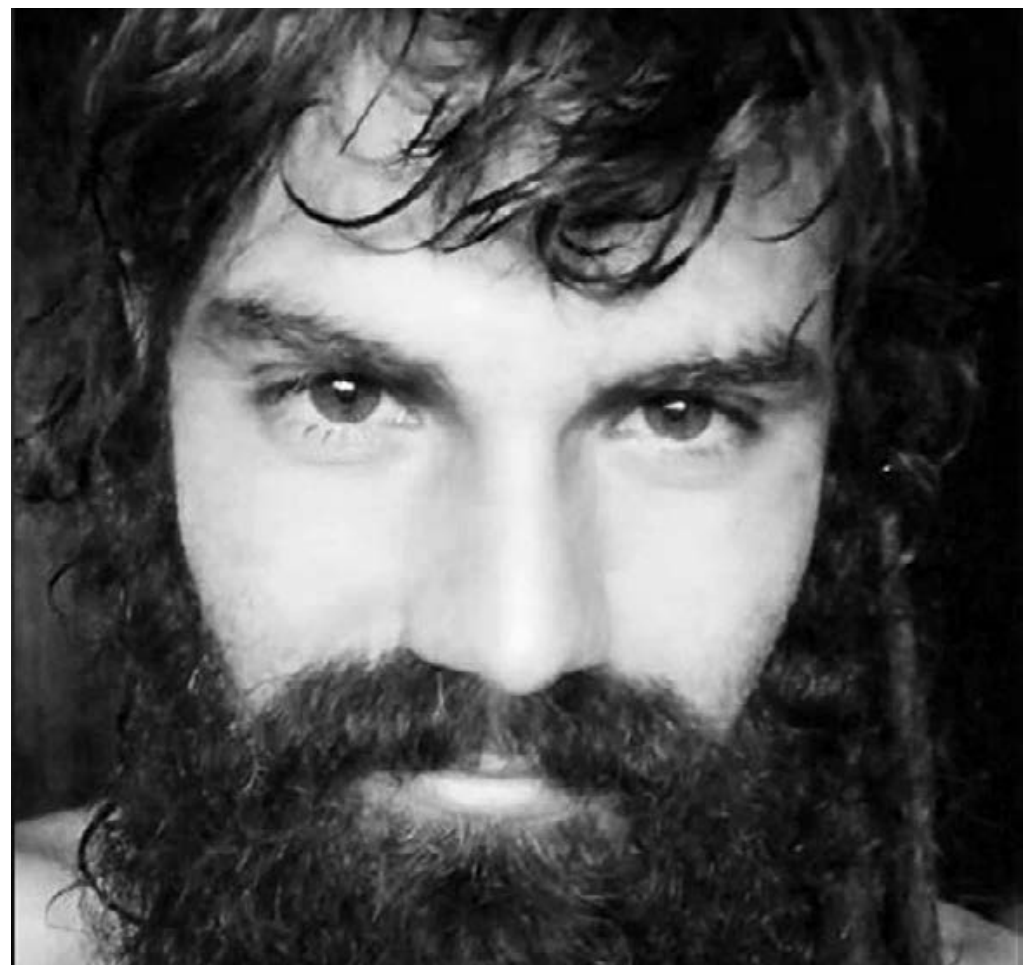

Figura 1. Fotografía de circulación pública de Santiago Maldonado. Fuente: Fotografía de circulación pública.

De manera general, cuando ocurren acontecimientos de este estilo, se crean y difunden imágenes, muchas veces disidentes y antagonistas, es decir, opuestas al discurso de un "otro", que en general es el poder hegemónico, en circunstancias de manifestaciones, movilizaciones y actos que buscan dar voz y visibilidad a esos hechos, catalogados como injustos, ilegales, autoritarios o abusivos. Así, se combinan colores, formas, texto e imagen: stencils, grafitis, murales, pancartas, accesorios corporales que acompañan y configuran la manifestación conflictual. Además, este tipo de experiencias reconfiguran el espacio con acciones que reconstruyen la memoria para la producción de un nuevo espacio social (Proaño 2016), diferente del que existía previamente.

Durante las manifestaciones realizadas en las que se pedía la aparición con vida de Santiago Maldonado, se ha hecho multiplicidad de stencils en las calles (imágenes caladas en una plantilla y reproducida en otra superficie usando aerosoles), para marcar su presencia en el espacio público. En la figura 2, vemos la imagen del cuerpo de Maldonado, de modo que su rostro, el que ha sido divulgado en diferentes medios y dispositivos artísticos, es el referente visual que permite reconocerlo. En su mano izquierda, lleva una lanza con la cabeza de la ministra de Seguridad de la Nación, Patricia Bullrich. La imagen es acompañada por una pregunta: "Si el Estado somos todos, ¿quién nos dispara?." En este sentido, se evidencia que hay una producción de un "nosotros"-"ellos" que está operando como mecanismo de diferenciación. Así, en este caso, "el otro" aparece a partir de la imagen de la ministra y, de forma textual, en la mención a Benetton.

Podemos indicar que aquí operó lo que Rancière (1996) denomina el "encuentro entre dos lógicas", dos tipos de reparto de lo sensible: el del gobierno, que denomina policía, y el de la igualdad, al que llama política. Recordemos que para el autor el reparto o división de lo sensible se refiere a la definición de lugares, espacios y tiempos que delimitan la 


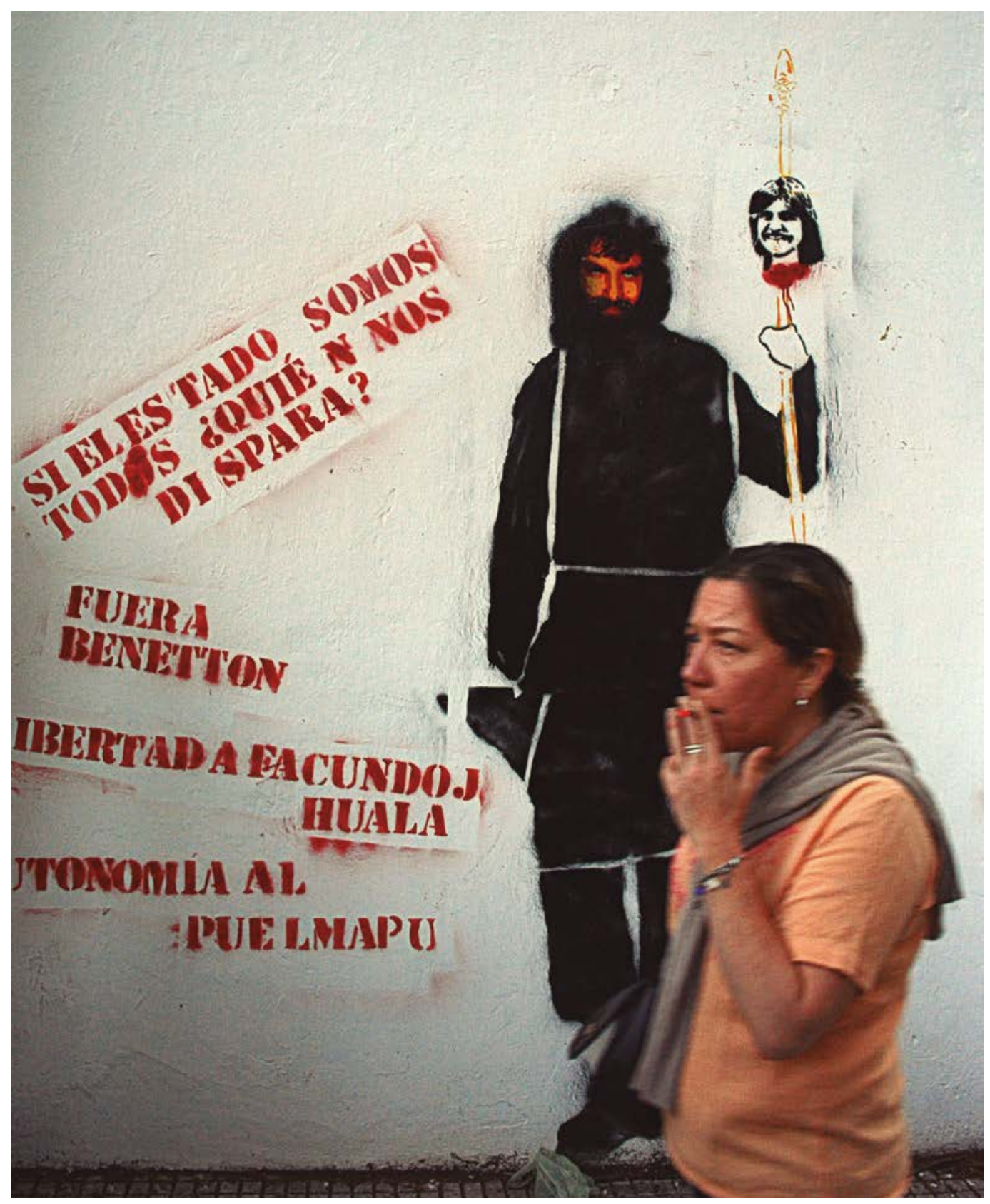

Figura 2. Stencil callejero, Ciudad de Buenos Aires, agosto de 2017. Fuente: Fotografía anónima.

existencia de lo común, lo que separa y excluye, por un lado, y lo que hace participar, por otro. De esta forma, la policía da cuenta de la distribución jerárquica de nombres, lugares, espacios y funciones, que los naturaliza y legitima, define lo que es visible y lo que no lo es, quiénes pueden hablar y quiénes no, y así dañan la igualdad de los que integran lo común. La política se identifica con la parte de los que no tienen parte, aquellos que aparecen y subvierten la división de los lugares y de las funciones. Para este autor, solo hay política cuando las maquinarias del orden policial son interrumpidas por el efecto del supuesto de la igualdad de cualquiera con cualquiera. La igualdad así pensada es, entonces, más que un principio o valor, el operador de una diferencia: ¿realmente somos todos iguales?, ¿entonces por qué algunos no pueden decir, hablar?, ¿por qué entonces a algunos se les dispara? 
Es decir, este stencil callejero está poniendo en evidencia la existencia desigual de un "nosotros" y un "ellos", en que unos pueden disparar y matar a los otros al no reconocerlos como parte del mismo todo social. Así, habría ciudadanos argentinos que valen y otros que no. Es a partir de los mensajes en las distintas intervenciones artísticas que se cuestiona lo dado y se enarbola otro discurso sobre lo sucedido, en este caso, apuntando a la continua represión sobre el Puelmapu, parte del territorio mapuche que está al este de la cordillera de los Andes, y a la ocupación de tierras mapuches por parte del empresario Benetton.

En las distintas marchas en las que se reclamaba por la aparición con vida de Santiago y justicia en relación con el hecho, han circulado frases como "El Estado es responsable," "El Gobierno sabe dónde está", "Macri-Bullrich-Noceti-Gendarmería. El negarlo no los hace inocentes. Ni olvido ni perdón". Aquí el Estado nacional en general y los representantes de los poderes públicos en particular (el presidente, la ministra de Seguridad Nacional, la Gendarmería) aparecen de forma manifiesta como un "otro" antagonista culpable de la desaparición —y posterior muerte- de Maldonado (figura 3).

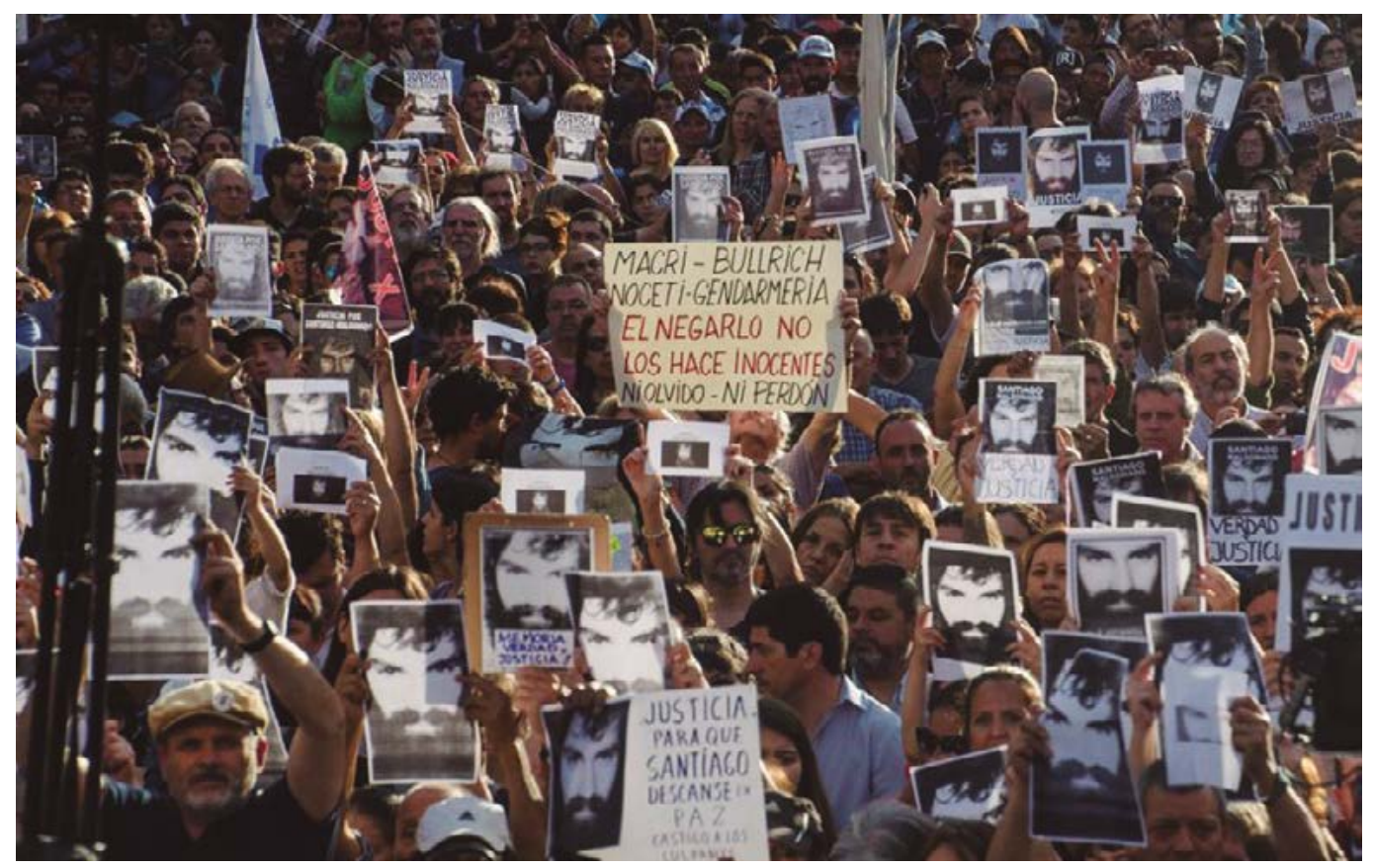

Figura 3. Fotografía de la marcha en Buenos Aires por la desaparición de Santiago Maldonado, 2017. Fuente: Fotografía de Kaloian Santos Cabrera.

Así, se cuestiona que Maldonado no se ahogó por su propia incapacidad para nadar, como señaló el discurso oficial, sino que primero desapareció tras la violenta represión de la Gendarmería —avalada por la ministra de Seguridad Nacional- y luego su cuerpo fue encontrado sin vida.

Estas consignas, en general, aparecen rodeadas de la reproducción casi infinita de la fotografía de su rostro, lo que le da un peso y una densidad específica al reclamo al vincularlo con una cara, con la singularidad de la persona, y retrotrae la protesta a un campo humano al mismo tiempo que político. Estas fotografías ubican en tiempo y en espacio real y actual la desaparición de una persona, así como dan un nombre al significante "desaparecido". El peso, entonces, está dado, además del tenor de las frases, por la multiplicación de lo singular, la insistencia de lo humano que, con las imágenes, atraviesa las consignas. 
La frase que acompañó a la mayoría de las manifestaciones visuales relacionadas con la desaparición de Maldonado es la pregunta: “¿Dónde está Santiago Maldonado?” (figura 4). Esta pregunta parece tener dos sentidos reconocibles: por un lado, se refiere a un interlocutor válido, el Gobierno, la Gendarmería o el propio empresario Benetton, es decir, que se produce con la intención de ser respondida por quienes son considerados responsables; por otro lado, resuena en el lugar de una pregunta retórica que remite a las desapariciones del pasado reciente, la mayoría de ellos jamás encontrados. ${ }^{2}$ Es preciso decir también que no solo hay un enlace con ese pasado reciente, sino que además con esa pregunta se vincula la desaparición de Maldonado con otros casos sucedidos en democracia. Así, por ejemplo, lo ocurrido rápidamente se emparentó con los casos de Jorge Julio López ${ }^{3}$ y de Luciano Arruga, ${ }^{4}$ entre otros.

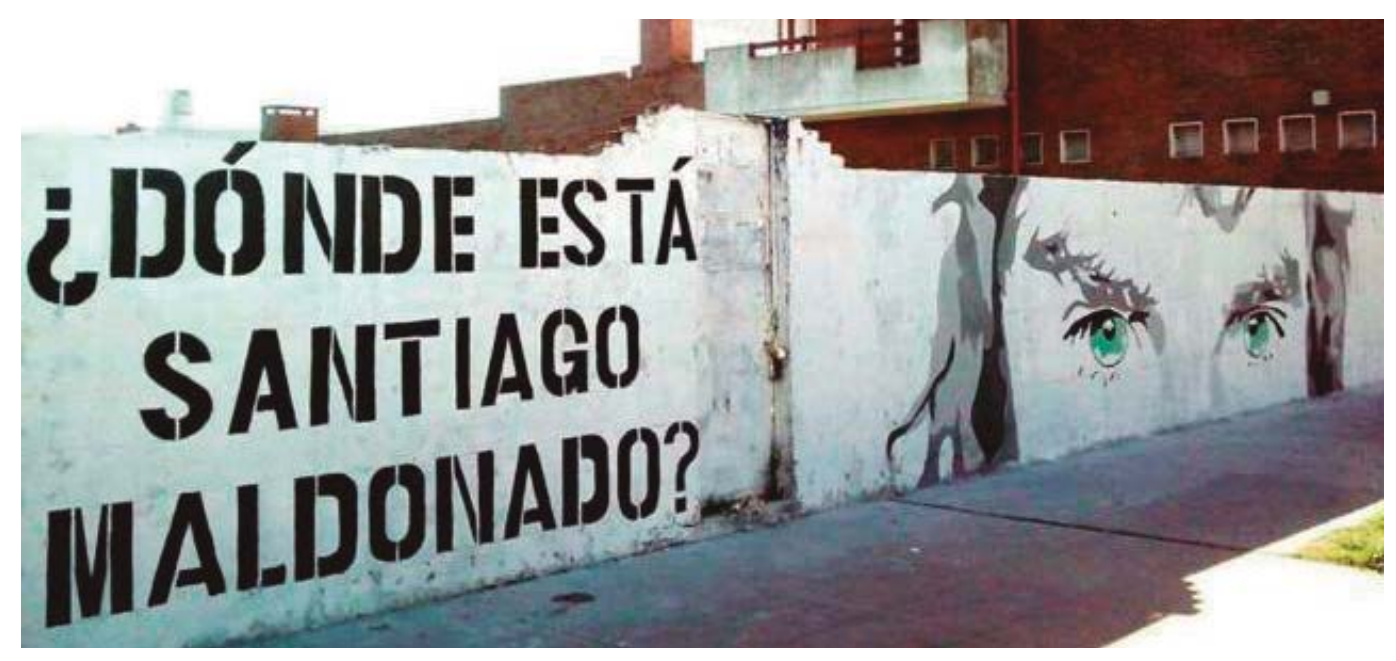

Figura 4. Mural producido por la Mesa de la Memoria de San Nicolás y el Colectivo Arquitectura del sur de Rosario, calles Chacabuco y Olleros, 1 de septiembre de 2017.

Fuente: Fotografía anónima.

\section{LA POLITICA EN MURALES}

A continuación, analizaremos cuatro murales realizados en la ciudad de La Plata en 2017. En ellos veremos características particulares y compartidas que se refieren a las cuestiones que hemos desarrollado previamente.

El primer mural seleccionado se llamó El Estado te desaparece, se encuentra en la avenida 1 entre calles 33 y 34 de La Plata (figura 5) y fue producido por el Comité de Solidaridad Santiago Maldonado, organización que se formó durante los 78 días que duró la ausencia forzada del joven. Fue pintado en 2017, luego tapado por manos anónimas y, finalmente, repintado en 2018. En este caso, como vimos en el stencil y en los carteles de la manifestación, el Estado es acusado de ser el responsable de la desaparición y con esto el principal interlocutor de las frases que rodean la imagen del rostro de Maldonado. " ¡Basta de reprimir al pueblo mapuche!" y "Macri, Bullrich y Noceti son responsables" forman parte del mural y establecen claramente un antagonismo con ellos. Asimismo, otras frases dialogan sobre violaciones a los derechos humanos, como el pedido de " ¡Libertad a Facundo Jones Huala ! !", vinculado con la represión al pueblo mapuche, y "Aparición con vida de Johana Ramallo", cuya desaparición se presume relacionada con la trata de personas y la negligencia del Estado. Una de las consignas que cierra el mural es "Basta de desapariciones forzadas", 
lo que engloba en una expresión los rostros pintados de otras personas, como Miguel $\mathrm{Bru}^{7}$ y Julio López, desaparecidos a manos de las fuerzas del Estado. El mural entonces se presenta como una plataforma de emisión textual y visual que produce un antagonista (en sintonía con la mayoría de las expresiones públicas de protesta sobre el caso Maldonado y los otros mencionados), al mismo tiempo que lo interpela como interlocutor a través de un reclamo específico que vincula la desaparición de Maldonado con otras diez ausencias inexplicables (al menos en los términos de la legalidad). Al mismo tiempo, este mural se transforma en un archivo visual de las desapariciones en dictadura, construye imágenes y textos que, primero, producen espacio público en tanto espacio político; segundo, dan cuerpo visual a una especie de galería del terror; y tercero, construyen una memoria visual, textual y espacial de las desapariciones en democracia. Estabilizan una memoria en la medida en que las reúnen en un único dispositivo que da visibilidad pública, hace visible lo que el orden policial, desde el punto de vista de Rancière (1996), oculta.

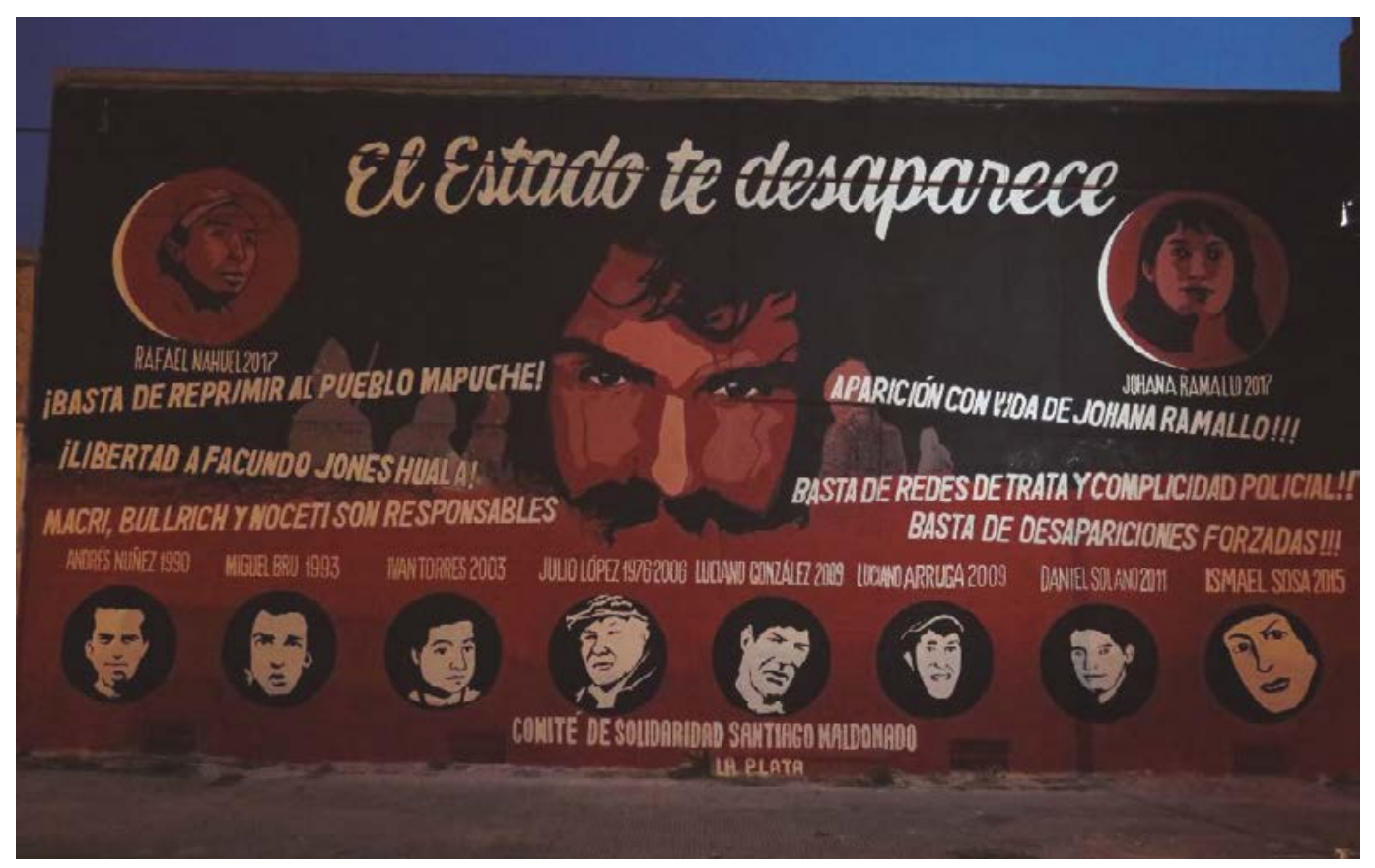

Figura 5. Mural del Comité de Solidaridad Santiago Maldonado, avenida 1 entre calles 33 y 34, La Plata, 2017. Fuente: Juan Cicale.

En concordancia con lo anterior, este mural fue efectivamente atacado, ya que se realizaron inscripciones y se cubrieron los rostros de los desaparecidos. ${ }^{8}$ Podríamos señalar que, lejos de cualquier paradoja, si el mural produce un archivo de las desapariciones que hace visible estos hechos, al ser tapado, se intenta volver al estado de cosas anterior, su ocultamiento, su negación. Velar los rostros sin tapar sus nombres es, sin embargo, un rasgo del cinismo que quiere oscurecer una parte pero deja entrever la función explícita de esa acción. Se evidencia así que en esta disputa por el espacio público de la calle se expresa también un conflicto en función de una relación de enemistad con un otro que, sin bien es anónimo, delimitó las tapaduras a partes específicas del mural con lo que demostró una intencionalidad. Esto manifiesta la politicidad del mural, su enfrentamiento con el orden policial, la posibilidad que brinda de hacer ver acontecimientos como estos y contextualiza la desaparición de Maldonado con otras desapariciones en democracia. 
El segundo mural por Santiago Maldonado que hemos relevado se realizó en la fachada de la pizzería platense Roots, ubicada en diagonal 73 y calle 56 (figura 6). Roots se presenta como un "colectivo de trabajo [...] dispuestx a deconstruir lógicas patronales desde la autogestión, la solidaridad y el compromiso" (Página de Facebook de Roots Pizza). En su página de Facebook, se manifestaron a favor del paro de las mujeres, ocurrido el pasado 8 de marzo, día en que las mujeres de esta cooperativa no trabajaron, por lo que se sumaron a la convocatoria internacional. En el mismo sentido, esta pizzería se expresó repetidamente a favor de la despenalización del aborto en momentos en que era discutida la ley en la legislatura argentina, así como colocaron en la fachada del local banderines verdes que representan la lucha por su legalización. El pasado 24 de marzo cerraron sus puertas en recuerdo del golpe de Estado y colocaron la frase "Ningún genocida suelto" (Facebook 2018). Entre otras causas, como el repudio al asesinato de Rafael Nahuel, ${ }^{9}$ también acompañaron el reclamo por la desaparición de Maldonado y la conmemoración a un año del evento a través de artículos en la red social. Estas expresiones de apoyo a causas claves en la actualidad argentina que tienen como interlocutor directo al Estado no son frecuentes en espacios comerciales que, en general, por una razón estratégica de mercado, tienden a evitar posicionamientos explícitos respecto de la realidad social y política. Esta cooperativa de trabajo decidió, así, colocar el rostro de Maldonado en una intervención realizada por el artista Guillermo "Chempes" y la artista Paz "Zapaz Flecha" en las vidrieras de su frente.

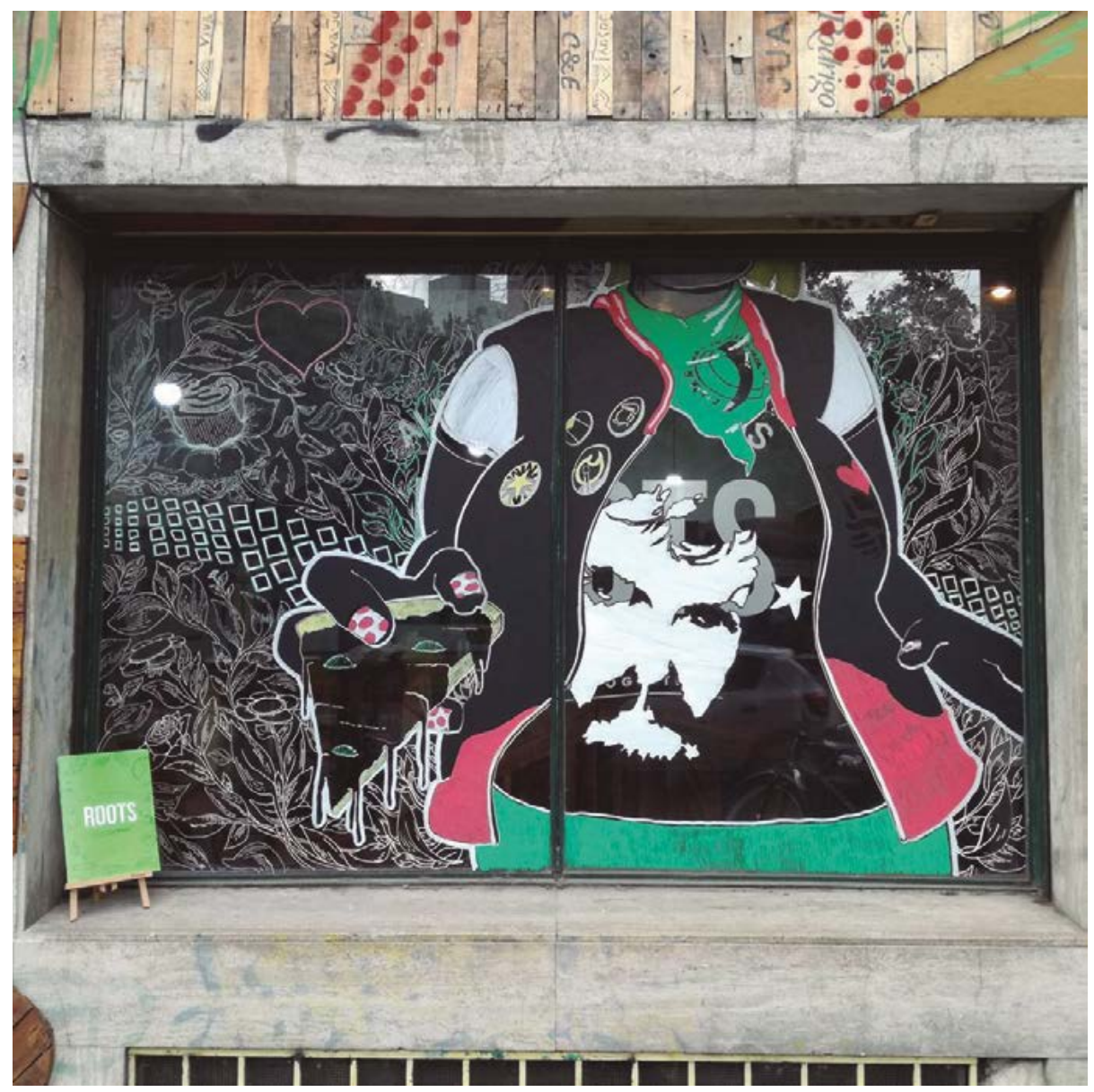

Figura 6. Mural en la fachada de pizzería Roots, diagonal 73 y 56, La Plata, 2017 Fuente: Guillermo "Chempes". 
Si los posicionamientos políticos de esta pizzería a través de sus artículos en internet eran destacados por su singularidad en el mercado - téngase en cuenta que un usuario comentó "iba a pedir una pizza y cuando vi esta asquerosa página que en vez de ofrecer un producto gastronómico ofrece solo propaganda política me arrepentí!! que tiene que ver la pizza con Maldonado o el aborto? Detestable!!!!" (Facebook 2018)—, la apropiación de la imagen de Maldonado en su propia fachada acentúa el carácter contestatario mantenido en la red social. Además, es interesante destacar que en el mural la imagen de Maldonado surge en la ropa de una persona que la porta, quien, al mismo tiempo, tiene colocado el característico pañuelo utilizado en la lucha social por la legalización del aborto. Esta persona aparece ofreciendo una porción de pizza. La llamativa combinación de elementos que expresa este mural lo hace único en el contexto del reclamo por la desaparición de Maldonado.

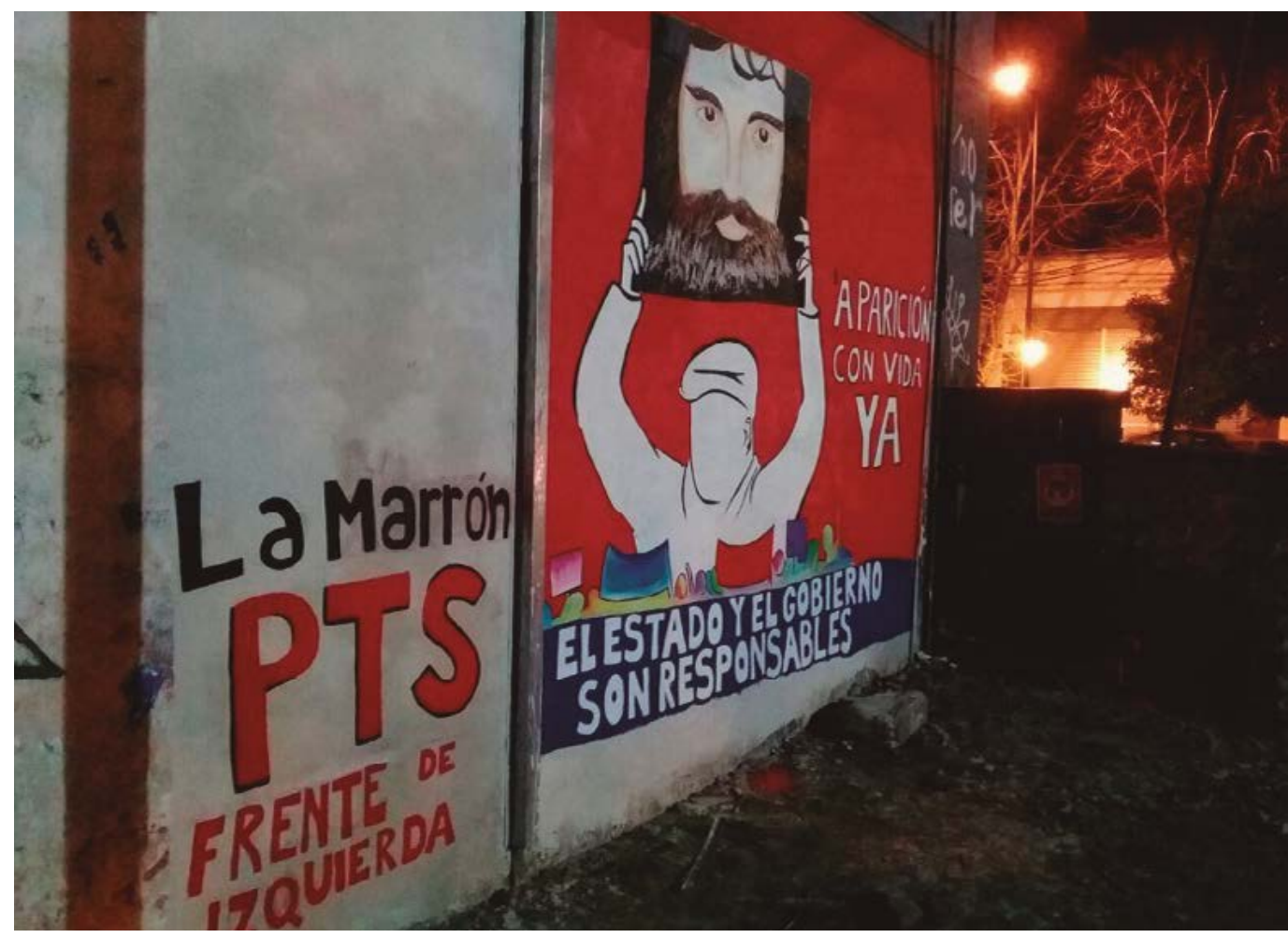

Figura 7. Mural colectivo en el centro de Los Hornos, realizado por estudiantes terciarios, docentes y trabajadores, calles 137 y 60, La Plata, 2017.

Fuente: Damsk8.

El tercer mural relevado en la ciudad de La Plata fue el realizado en el centro de Los Hornos, específicamente en la esquina de las calles 137 y 60 el 16 de septiembre de 2017 (figura 7). La imagen fue hecha por estudiantes terciarios y docentes. Lo interesante de esta intervención fue que surgió como reacción a la campaña instalada desde el Gobierno del presidente Mauricio Macri que instó a denunciar —haciendo circular una línea telefónica gratuita 0800- a los docentes que mencionaran a Maldonado en sus clases. Es preciso indicar que el impacto que tuvo en parte de la sociedad civil la desaparición de Santiago en el contexto de una represión llevó a que en varios contextos educativos se desarrollaran debates al respecto. Además, la fecha elegida para pintar el mural también es significativa por dos razones. En primer lugar, porque los 16 de septiembre se conmemora en la ciudad de La Plata lo que se llamó "La noche de los lápices", recordando a un grupo de jóvenes 
estudiantes secundarios que fueron secuestrados y desaparecidos el 16 de septiembre de 1976 por la última dictadura al reclamar por el boleto estudiantil secundario. En segundo lugar, por la cercanía de un nuevo aniversario de la segunda desaparición forzada de Jorge Julio López ocurrida el 18 de septiembre de 2006.

En este caso, la producción artística es mucho más simple que en los dos murales anteriores: aparece, sobre un fondo rojo, el dibujo de su rostro, tal como vimos en la figura 1, que es sostenido a modo de cartel por la silueta de Jorge Julio López. Como señalamos, López es un desaparecido en democracia (vecino de Los Hornos), al igual que Maldonado en ese momento. Aquí, se pintó sin rasgos faciales o corporales, solo se ve el contorno de la cara y su boina, lo que funciona como anclaje para que se lo reconozca. La metáfora surge como referencia al hecho sin necesidad de ocultar a la persona, a diferencia de lo que ocurrió en el denominado Siluetazo en $1983 .^{10} \mathrm{La}$ imagen del mural es acompañada por dos frases: "Aparición con vida ya" y "El Estado y el Gobierno son responsables". La primera vincula el hecho de la desaparición de Maldonado en el presente con los desaparecidos en el pasado y el pedido de aparición con vida. La segunda frase ubica nuevamente a los culpables de lo sucedido.

El cuarto mural elegido en este artículo es el realizado por vecinos autoconvocados en la calle 5 entre las calles Arana y 421 de Villa Elisa, también en 2017. En este caso, adquiere relevancia el rostro de Santiago que fue pintado emulando la fotografía de la figura 1, tal como en el tercer mural analizado. Se incluye además la pregunta "¿Dónde está Santiago?". Esta intervención fue violentada, al igual que sucedió con el primer mural que describimos, dado que la imagen de Maldonado apareció tapada por postes de madera que fueron colocados frente al muro, lo que generó preocupación entre los vecinos del barrio, pues fue visto como un avasallamiento contra la intención de generar memoria y reflexión sobre lo acontecido. Si bien no hubo nadie que se reconociera como responsable por la colocación de los postes, se cree que fueron agentes de la delegación municipal por el tipo de trabajo realizado, gobierno que pertenece al mismo partido político que las autoridades nacionales, acusadas -al menos socialmente- de ser los responsables del caso Maldonado (1894a 2017; 1894b 2017).

Por otro lado, ha sido interesante lo ocurrido en el lugar del mural una vez que se conoció la noticia de la aparición sin vida del cuerpo de Maldonado. Apenas confirmada la identidad del cuerpo, un grupo de vecinos se reunió en el lugar e improvisó un santuario con velas al tiempo que reclamaron justicia por la muerte de Santiago (figura 8).

Consideramos que esta acción promueve una nueva actualización del lugar. Da Silva Catela (2001) analizó en varios de sus escritos rituales de conmemoración, y si bien lo hizo en relación con la actualización de espacios y modos de expresión asociados a los desaparecidos tras la dictadura cívico-militar iniciada en 1976, sus aportes también permiten iluminar este tipo de prácticas, asociadas a otros contextos. De esta forma, podemos pensar que este tipo de espacios pueden posibilitar la comunicación y expresión de los sufrimientos y de las emociones tras una tragedia, y sobrepasar las fronteras familiares, lo que habilita espacios compartidos y públicos potenciales. De esta forma, las velas fueron utilizadas para recordar a quien ya pasaría de ser un desaparecido en democracia a ser un muerto en circunstancias extraordinarias. La pregunta que sostiene este mural, como tantas otras expresiones populares sobre el caso, "¿Dónde está?", tenía finalmente una respuesta, su cuerpo había aparecido, pero las causas de su muerte resultaron altamente sospechosas, no solo para familiares y amigos de Maldonado, sino para la sociedad en general. 


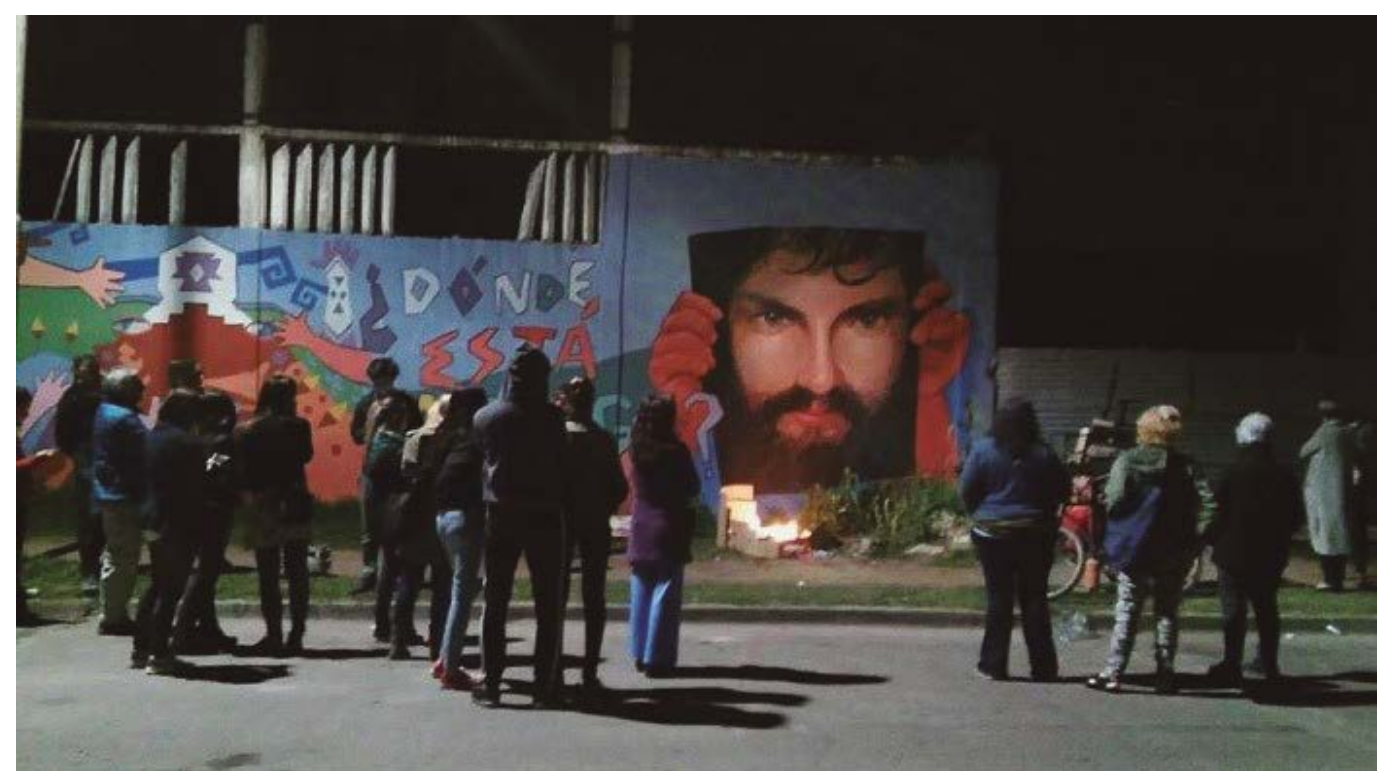

Figura 8. Mural realizado por vecinos autoconvocados, calle 5 entre calles Arana y 421 de Villa Elisa, La Plata, 2017. Fuente: Fotografía anónima.

En suma, a partir de los cuatro murales analizados, podemos exponer varias cuestiones. En primer término, la centralidad que adquiere la imagen de Maldonado, derivada de su fotografía y replicada en distintos soportes (carteles, paredes, espacio virtual). Así, el arte aparece como "lugar" de enunciación privilegiado para el abordaje de temas controversiales socialmente, y aporta a su visualización. Un segundo aspecto es la apropiación del espacio público a partir de la construcción de un discurso antagonista que en ocasiones ha materializado el conflicto a causa de acciones que violentaron los murales. A través de un anclaje verbal, se explicita a los considerados culpables por la desaparición de Maldonado. En tercer lugar, identificamos la generación de marcas societales de memoria que emergieron a partir de prácticas emprendidas desde diversos sectores de la sociedad civil. Es decir, diferentes actores —colectivos culturales, artistas, docentes, estudiantes, vecinos autoconvocadoshan inscripto, señalado y marcado diversos espacios a partir de prácticas visuales ligadas a la desaparición de Maldonado. Por último, un cuarto punto es, por un lado, el vínculo existente entre presente y pasado, entre la desaparición forzada de un ciudadano en democracia y las desapariciones ocurridas en el contexto de la última dictadura cívico-militar y, por otro, el nexo entre la desaparición de Santiago y la de otras personas en el contexto de un supuesto Estado de derecho, desapariciones ligadas a casos de gatillo fácil, trata de personas, etc.

\section{CONCLUSIONES}

En el espacio público, tienen lugar manifestaciones políticas, sociales, culturales e instancias de participación social que se vinculan con la coyuntura histórica. Estas prácticas modifican y moldean el espacio público, lo conforman y lo definen. Allí se producen instancias de enunciación que pueden interpelar al orden de cosas hegemónico, entre ellas, la proliferación de performances, intervenciones y obras artísticas de participación colectiva. Estas propuestas irrumpen en un espacio de tránsito, anónimo, que lo vuelven significativo y generan nuevos espacios, en ocasiones, de disenso. Entonces en el espacio construido 
socialmente confluyen cierta distribución del poder, el conflicto social y también las prácticas creativas que muchas veces se proponen generar operaciones contra las dinámicas de organización hegemónicas. Los murales analizados, inscriptos en las prácticas del activismo artístico, permitieron tramitar el hecho de la desaparición de Maldonado en una escala local, lo que tiene "un papel fundamental a la hora de restablecer la memoria en el paisaje cotidiano de los ciudadanos" (Schindel 2009, 82). Esto permite no solo mantener vigente públicamente ciertos temas, sino también dar batalla por el sentido de esos acontecimientos.

En los cuatro murales, el tema es el mismo, la desaparición de Santiago Maldonado, sin embargo, lo interesante es que cada caso es particular, ya que fue emprendido por diferentes actores sociales, aunque todos asumieron la responsabilidad política de visibilizar la ausencia. Como sostuvimos antes, estos murales, como otras expresiones culturales respecto del caso, al visibilizar lo que se quería ocultar, disputaron al orden policial —para decirlo en los términos de Rancière (1996) - el discurso y la representación de los hechos, lo enmarcaron en un proceso de enunciación que permitió hacer ver y decir un discurso enfrentado con el que sostenía el Gobierno. Este acontecimiento atravesó diversas capas de la sociedad civil, aunque también profundizó una división en ella entre quienes reclamaban justicia y conocer la verdad, y quienes culpaban a la víctima por lo sucedido.

En estos casos, hemos visto de qué modo arte y política se enlazan entre sí, ya que en el corpus de imágenes analizadas podemos ver que la producción artística permitió poner en escena y a la vez producir el conflicto -en particular en aquellos casos en los que un "otro" tapa o violenta los murales- a través de materialidades expresivas que los sujetos eligen y crean para hacerse ver y oír, además de la palabra. Supone otra "discursividad". Es decir, las imágenes construidas en los murales expusieron y disputaron la representación del acontecimiento, por ejemplo, señalando a los culpables. Pero a la vez vinculaban este hecho con otras luchas consideradas importantes (como la Ley por Derecho al Aborto Legal, Seguro y Gratuito) y con otros casos ligados al accionar represivo del Estado (Julio López, Luciano Arruga, Johana Ramallo, el avasallamiento contra pueblos originarios, etc.). De este modo, produjeron una articulación de demandas sociales que excede al caso Maldonado y que apunta a un nivel de transformación social mayor.

En relación con esto último, además, las expresiones artísticas sobre Maldonado funcionaron como marcas societales de memoria, tanto a través del uso de la fotografía de su rostro que remite a las desapariciones durante la última dictadura en Argentina como en la producción de un archivo visual de la memoria de las desapariciones en democracia. Así, si bien no se pretende afirmar que este tipo de prácticas autogestivas generaron una transformación total en el estado de cosas, su aporte radicó en que los recursos estéticos, referidos a una coyuntura histórica particular, funcionaron como un repertorio de acciones sustanciales para la política desde el punto de vista de la oposición al orden dominante, la comunicación pública, la visibilización de demandas y las prácticas de solidaridad. 


\section{NOTAS}

1. El entorno de Santiago Maldonado creó, al poco tiempo de ocurrida su desaparición, una página web donde divulgaron noticias, comunicados y todo lo relativo a la causa judicial. Para más información, véase en: http://www.santiagomaldonado.com/

2. En las causas judiciales por delitos de lesa humanidad, algunos restos óseos de personas desaparecidas fueron encontrados y restituidos a sus familiares.

3. Julio López, desaparecido desde octubre de 1976 hasta junio de 1979 durante la dictadura de 1976, desapareció por segunda vez el 18 de septiembre de 2006, luego de la condena al genocida Miguel Etchecolatz. Habiéndose derogado las leyes de Obediencia Debida y Punto Final, Etchecolatz fue el primer acusado por genocidio. López era querellante en la causa y un testigo clave, ya que sus declaraciones involucraban a muchos militares y policías. Todavía hoy sigue desaparecido y no se sabe nada de su paradero.

4. Joven desaparecido en democracia. El 31 de enero de 2009 fue secuestrado por la policía bonaerense en Lomas del Mirador, La Matanza, en represalia a su negativa de robar para la policía. Ninguno de los efectivos acusados fue procesado. Tenía 16 años. El 17 de octubre de 2014 apareció su cuerpo enterrado como NN.

5. Líder mapuche que reclama tierras de Argentina y Chile. El Gobierno chileno lo acusa de terrorista.

6. Joven de 23 años, vista por última vez el 26 de julio de 2017. La familia y sus abogadas denunciaron que fue secuestrada por una red de trata de personas.

7. Joven de 23 años, estudiante de Periodismo y desaparecido el 17 de agosto de 1993 luego de haber sido detenido y torturado en la Comisaría 9. ${ }^{a}$ de La Plata. Su muerte quedó comprobada a través de testigos y pruebas. Su cuerpo nunca fue encontrado.

8. Pueden verse imágenes de la vandalización y posterior repintado en Agencia de Noticias Red Acción (2018).

9. Joven mapuche de 21 años que resultó muerto en Bariloche durante un operativo del grupo Albatros de la Prefectura Naval Argentina en noviembre de 2017. Las pericias indican que agentes de la fuerza de seguridad nacional dispararon mientras Nahuel estaba de espaldas y desarmado.

10. Experiencia colectiva que se produjo en nuestro país el 21 de septiembre de 1983 durante la Tercer Marcha de la Resistencia organizada por las Madres de Plaza de Mayo. El proyecto fue pensado por Rodolfo Aguerreberry (1942-1997, docente y artista), Guillermo Kexel (1953, diseñador, serígrafo y artista) y Julio Flores (1950, docente y artista). A partir de producir contornos humanos en representación de los desaparecidos, se buscaba hacer visible el reclamo de aparición con vida de los desaparecidos en el contexto aún del Gobierno de facto. La confección de siluetas anónimas de tamaño natural fue una forma de representar "la presencia de una ausencia" con una apropiación del espacio urbano, que dejó de ser cotidiano para ser un espacio de rebelión que hacía consciente la magnitud del genocidio, invitando a reflexionar, pensar, problematizar. Así, el desaparecido aparecía simbolizado en el espacio público, el espacio de lo común, y se les asignaba a los cuerpos ausentes un lugar.

\section{REFERENCIAS}

Agencia de Noticias Red Acción. 2018. "Fotogalería: Restauración del mural por Santiago Maldonado en La Plata". Consultado: 20 de agosto de 2018. http://www.anred.org/?p=93844

Ámbito.com. 2013. "Su frase más perversa sobre los desaparecidos". Consultado: 24 de septiembre de 2018. https://www.ambito.com/su-frase-mas-perversa-los-desaparecidos-n3788810

Bugnone, Ana. 2018. "Un campo reverberante: Hélio Oiticica, Lygia Pape y Edgardo Vigo". Aisthesis 63:2754. http://revistaaisthesis.uc.cl/index.php/rait/article/viewFile/108/1033

Capasso, Verónica. 2016. “Espacio social: aportes para una definición del concepto y su posible relación con el arte". Ponencia presentada en XIV Seminário de História da Cidade e do Urbanismo. Cidade, arquitetura e urbanismo: visoes e revisoes do século XX acuerdo de cesión de derechos, São Carlos, São Paulo, Brasil, 13-15 de septiembre. 
Da Silva Catela, Ludmila. 2001. No habrá flores en la tumba del pasado: la experiencia de reconstrucción del mundo de los familiares de desaparecidos. La Plata: Ediciones Al Margen.

Expósito, Marcelo, Jaime Vindel y Ana Vidal. 2012. "Activismo artístico." En Perder la forma humana: una imagen sísmica de los años ochenta en América Latina, 43-50. Madrid: Museo Nacional Centro de Arte Reina Sofía.

Página de Facebook de Roots Pizza. Consultado: 24 de septiembre de 2018. https://es-la.facebook.com/ Roots-Pizza-480590965381459/

Felshin, Nina. 2001. “¿Pero esto es arte? El espíritu del arte como activismo." En Modos de hacer: arte crítico, esfera pública y acción directa, 73-94. Salamanca: Universidad de Salamanca.

Gorelik, Adrián. 1998. La grilla y el parque: espacio público y cultura urbana en Buenos Aires, 1887-1936. Buenos Aires: Universidad Nacional de Quilmes.

Gresham Beamer, Emily. 2017. “¿Dónde está Santiago Maldonado? El uso del retrato y el activismo artístico para exigir la 'aparición con vida' de las desapariciones forzadas en Argentina". Independent Study Project (ISP) Collection 2658. https://digitalcollections.sit.edu/isp_collection/2658/

Jelin, Elizabeth. 2017. La lucha por el pasado: cómo construimos la memoria social. Buenos Aires: Siglo XXI.

Lefebvre, Henri. 2013. La producción del espacio. Madrid: Capitan Swing.

Longoni, Ana. 2011. "Tres coyunturas del activismo artístico en la última década". En Poéticas contemporáneas: itinerarios en las artes visuales en la Argentina de los 90 al 2010, 43-46. Buenos Aires: Fondo Nacional de las Artes.

Massey, Doreen. 2008. Pelo espaço: uma nova política da espacialidade. Río de Janeiro: Bertrand Brasil.

Pírez, Pedro. 1995. "Actores sociales y gestión de la ciudad". Ciudades 28:8-14. http://www.cedet.edu.ar/ Archivos/Bibliotecas/pirez_actores.pdf

Proaño Gómez, Lola. 2016. "Espacialización de la memoria, 'memoria actual' y política en el teatro comunitario argentino (1983-2016)". Afuera, estudios de crítica cultural 17/18:1-20. https://drive. google.com/file/d/0B5WgfB6_mzjmZU5SbWJRaGF3SjA/view

Rabotnikof, Nora. 2005. En busca de un lugar común: el espacio público en la teoría política contemporánea. México: Instituto de Investigaciones Filosóficas.

Rancière, Jacques. 1996. El desacuerdo: política y filosofía. Buenos Aires: Nueva Visión.

Schindel, Estela. 2009. "Inscribir el pasado en el presente: memoria y espacio urbano". Política y Cultura 31:65-87. http://www.scielo.org.mx/scielo.php?script=sci_arttext\&pid=S0188-77422009000100005

Soria, Sofía. 2017. "¿Dónde está Santiago Maldonado? Tres imágenes". Cuadernos de Coyuntura 1:51-55. https://revistas.unc.edu.ar/index.php/CuadernosConyuntura/article/view/18755

Vargas, Mercedes. 2017. "En la frontera, un refugio para la cultura". Cuadernos de Coyuntura 1:57-60. https://revistas.unc.edu.ar/index.php/CuadernosConyuntura/article/viewFile/18756/18600

1894a, Radio Online de Villa Elisa. 2017. ¿Quién tapó el mural de Santiago Maldonado en Villa Elisa?". Consultado: 24 de septiembre de 2018. http://1894radioonline.com.ar/que-tapo-el-mural-de-santiagomaldonado-en-villa-elisa/

1894b, Radio Online de Villa Elisa. 2017. “El mural de Villa Elisa también fue centro del reclamo por Justicia para Santiago". Consultado: 24 de septiembre de 2018. http://1894radioonline.com.ar/el-mural-devilla-elisa-fue-otro-corazon-del-reclamo-por-justicia-para-santiago/ 